\title{
ANALISIS PERMINTAAN RUMAH TANGGA TERHADAP BERAS PRODUKSI KABUPATEN KUBU RAYA
}

\author{
IKE DEVIANA ${ }^{1}$, NOVIRA KUSRINI ${ }^{2}$, ADI SUYATNO ${ }^{2}$ \\ ${ }^{1}$ Alumni Magister Manajemen Agribisnis Fakultas Pertanian \\ Universitas Tanjungpura Pontianak \\ ${ }^{2}$ Staf Pengajar Fakultas Pertanian Universitas Tanjungpura Pontianak
}

\begin{abstract}
The purpose of this thesis is " To know the factors - factors that berpengaruhi in household demand on rice production Kubu Raya district and to determine the elasticity of demand for domestic rice production Kubu Raya District ". The method used in this study uses survey research locations selected by purposive sampling ( intentionally ) and respondents were selected directly at the study site ( accidental ) that is at the center of local sales of processed rice farmers Kubu Raya district ( Store Langsat Mas ). Criteria for respondents who selected that consumer households who are married and are buying local rice ( rice produced by farmers in Kubu Raya district ) of sample was 40 respondents .. The variables examined in the study are the following : 1 ) Number of Family Members , 2 ) Local Rice Price , 3 ). Non- local rice prices . , 4 ) . Household income. The results showed household demand functions to rice production Kubu Raya District as follows :

Ln Y $=-2.621+0.127+1.536 \ln$ JTK $\operatorname{lnPdp}-0.163+0.358 \ln \mathrm{Hbl} \operatorname{lnHbn}+\mathrm{e}$ Domestic demand on rice production Kubu Raya regency significantly influenced by the number of family members while the local rice price factors, the price of rice non-local factors and factors of household income had no significant effect . Price elasticity at the request of the households of Kubu Raya regency rice production is inelastic, income elasticity suggests that local rice is included in the category of normal goods and that the cross-price analysis based on non- local rice is included as substitutes.
\end{abstract}

Keywords : Demand, Local Rice, Kubu Raya, Elasticity .

\section{PENDAHULUAN}

Pada tahun 1978, Thomas Malthus memberi peringatan bahwa jumlah manusia akan meningkat secara eksponensial, sedangkan usaha pertambahan persediaan pangan hanya dapat meningkat secara aritmatika, sehingga akan terjadi sebuah kondisi dimana dunia akan mengalami kekurangan pangan akibat pertambahan ketersediaaan pangan yang tidak sebanding dengan pertambahan penduduk. Perkiraan Malthus telah mempengaruhi kebijakan pangan internasional, antara lain melalui revolusi hijau yang sempat dianggap berhasil meningkatkan laju produksi pangan dunia sehingga melebihi laju pertambahan penduduk. Pada saat itu, variable yang dianggap sebagai kunci sukses penyelamat ketersediaan pangan adalah teknologi (Nasoetion, 2008).

Program pembanguan pertanian di Indonesia dimulai sejak Pelita Pertama, produksi beras menunjukkan kecenderungan meningkat, puncaknya pada tahun 
1984 Indonesia telah menyatakan diri sebagai Negara yang berswasembada beras. Dengan berjalannya waktu kondisi produksi beras di Indonesia tidak selalu stabil, mengalami kenaikan dan penurunan. Dalam rentang waktu 10 tahun yaitu tahun 1994 Indonesia sudah tidak lagi berswasembada beras (Sapuan, 1999: 24).

Produksi beras Indonesia jauh tetinggal dari permintaan, sementara tingkat partisipasi konsumsi beras baik di kota maupun desa, di Jawa maupun di luar Jawa cukup tinggi yaitu 97-100 persen, ini berarti hanya 3 persen rumah tangga yang tidak mengkonsumsi beras (Achmad, 2001: 39).

Besarnya keterkaitan antara konsumsi beras dengan pendapatan diperkuat juga dengan data konsumsi tahun 1996 dan 1999. Pada tahun 1996 konsumsi beras di kota dan di desa masing-masing adalah 108,89 kg dan 120,97 per kapita. Setelah adanya krisis ekonomi, yang diperkirakan menyebabkan turunnya pendapatan rumah tangga, konsumsi beras di kota dan di desa pada tahun 1999 telah berkurang menjadi $96 \mathrm{~kg}$ dan $111,78 \mathrm{~kg}$ per kapita (BPS : 2008).

Kebutuhan akan beras di Indonesia tiap tahunnya meningkat,demikian juga di Kalimantan Barat termasuk di Kabupaten Kubu Raya. Hal ini disebabkan olek karena beras merupakan makanan pokok $97 \%$ rakyat Indonesia .Di Indonesia mengkonsumsi beras tertinggi di Asia yaitu $102 \mathrm{~kg} / \mathrm{kapita} / \mathrm{tahun}$, sedangkan di Korea $40 \mathrm{~kg} / \mathrm{kapita} / \mathrm{tahun}$, Jepang $50 \mathrm{~kg} / \mathrm{kapita} / \mathrm{tahun}$, Malaysia 80/kg/tahun dan Thailand $70 \mathrm{~kg} / \mathrm{kapita} /$ tahun. Indonesia pernah mengkonsumsi beras $139 \mathrm{~kg} / \mathrm{kapita} / \mathrm{tahun}$.

Untuk Kalimantan Barat, pemerintah telah menetapkan bahwa provinsi ini sebagai salah satu lumbung berasnya untuk kepulauan Kalimantan. Oleh karena itu sentra produksi padi di Kalimantan Barat diharapkan akan mampu umtuk meningkatkan produksi pertaniannya.

Pada tahun 2012 provinsi Kalimantan Barat memiliki produksi beras mencapai 717.909 ton, sebagian besar dengan konsumsi mencapai 629.654 ton dan mengalami surplus mencapai 90.251 ton. Beberapa daerah yang dapat diandalkan sebagai sentra produksi beras karena nilai surplus beras yaitu Kabupaten Sambas, Kabupaten Landak, Kabupaten Kubu Raya, Kabupaten Pontianak, Kabupaten Bengkayang dan Kabupaten Kayong Utara. Secara spesifik Kabupaten Kubu Raya sebagai daerah pemekaran telah mampu menjadi penyuplai beras yang cukup besar di Kalimantan Barat.

Permintaan akan beras dari tahun ke tahun semakin bertambah, hal ini disebabkan oleh pertambahan penduduk yang besar di Indonesia, termasuk di Kabupaten Kubu Raya. Rata-rata pertumbuhan penduduk di Indonesia masih termasuk tinggi yaitu 1,49\% / tahun atau setara dengan 3,5 juta jiwa per tahun. Sedangkan di Kalimantan Barat rata - rata pertambahan penduduk 0,91\% , dengan jumlah penduduk 4.052.345 jiwa di tahun 2005 menjadi 4.395 .083 jiwa di tahun 2010. Pertumbuhan penduduk di Kabupaten Kubu Raya sebesar 1,57 \% dengan jumlah penduduk 544.094.

Pada saat ini pemerintah Kabupaten Kubu Raya sedang melaksanakan program pemberdayaan petani melalui peningkatan produksi beras lokal dimana sasaran yang akan dipenuhi adalah untuk pemenuhan kebutuhan beras di Kalimantan Barat.

Kabupaten Kubu Raya memiliki luas areal penanaman padi mencapai 61,029 ha dan luas panen Kabupaten Kubu Raya yang mencapai 60.032 ha. Dengan luas areal tanam padi terbesar adalah pada kecamatan Sungai Kakap 
seluas 19.261 ha, sehingga wilayah kecamatan Sungai Kakap merupakan sentra utama komoditi padi pada Kabupaten Kubu Raya. Kecamatan Sungai Kakap merupakan daerah yang dapat mewakili dan menggambarkan keadaan perkembangan usahatani padi di Kabupaten Kubu Raya. Diharapkan Kecamatan Sungai Kakap sebagai sentra utama komoditi padi di Kabupaten Kubu Raya dapat memenuhi kebutuhan konsumsi dan permintaan beras di Kalimantan Barat dan Kubu Raya khususnya yang semakin meningkat diikuti dengan peningkatan pertumbuhan penduduk.

Dengan latar belakang inilah dilakukan analisis lebih lanjut dalam bentuk tugas akhir tesis yang berjudul : Analisis Permintaan Rumah Tangga Terhadap Beras Produksi Kabupaten Kubu Raya.

\section{Rumusan Masalah}

Dari latar belakang yang telah dikemukakan diatas, maka rumusan masalah dalam penelitian ini agar dapat terlaksana secara terarah, yaitu :

1. Faktor-faktor apa saja yang mempengaruhi permintaan rumah tangga terhadap beras produksi Kabupaten Kubu ?

2. Bagaimana elastisitas permintaan rumah tangga terhadap beras produksi Kabupaten Kubu Raya?

\section{Tujuan Penelitian}

Adapun tujuan dari penelitian ini adalah :

1. Untuk mengetahui faktor-faktor yang berpengaruh dalam permintaan rumah tangga terhadap beras produksi Kabupaten Kubu.

2. Untuk mengetahui elastisitas permintaan rumah tangga terhadap beras produksi Kabupaten Kubu Raya.

\section{METODE PENELITIAN}

\section{Metode dan Lokasi Penelitian}

Metode penelitian ini dilakukan dengan metode survei. Metode survei yaitu penyelidikan yang diadakan untuk memperoleh fakta-fakta dari gejala-gejala yang ada dan mencari keterangan-keterangan secara aktual, baik tentang institusi, sosial, ekonomi atau politik dari suatu daerah (Nazir, 1983: 65).

Teknik pengambilan sampel lokasi dilakukan dengan menggunakan teknik purpossive sampling ( sengaja ), yaitu dilakukan pada pusat penjualan beras lokal olahan petani di Kabupaten Kubu Raya ( Toko Langsat Mas ). Menurut Pasaribu (1983); Hermawan (2005); Suratno dan Arsyad (1999), pengertian purposive sampling adalah memilih sampel secara sengaja dengan pertimbangan-pertimbangan khusus atau berdasarkan kriteria tertentu yang dimiliki lokasi tersebut. Lokasi penelitian dilakukan dengan pertimbangan sebagai berikut lokasi tersebut merupakan toko yang banyak dikunjungi pembeli selain untuk konsumsi langsung maupun pedagang pengecer, relatif dekat dengan sejumlah pasar dan supermarket serta belum pernah dilakukan penelitian serupa.. Penelitian dilaksanakan selama 4 bulan dimulai bulan Maret 2013 sampai dengan bulan Juli 2013

\section{Populasi dan Teknik Pengambilan Sampel}

Soegiyono (2005) mengungkapkan bahwa populasi adalah wilayah generalisasi yang terdiri atas objek atau subjek yang mempunyai kuantitas dan karakteristik tertentu yang ditetapkan oleh peneliti untuk dipelajari dan kemudian ditarik kesimpulannya. Populasi diuraikan juga menurut Nawawi (1990) adalah 
keseluruhan objek penelitian yang terdiri dari manusia, benda-benda, tumbuhtumbuhan, gejala-gejala, nilai test atau peristiwa-peristiwa sebagai sumber data yang memilki karakteristik tertentu dalam suatu penelitian.

Responden dipilih langsung di lokasi penelitian ( accidental) Kriteria untuk responden yang dipilih adalah konsumen ( rumah tangga ) yang sudah berkeluarga dan sedang membeli beras lokal ( beras yang dihasilkan atau diproduksi oleh petani Kabupaten Kubu Raya ) pada pusat penjualan beras olahan petani Kabupaten Kubu Raya dan bersedia untuk mengisi kuesioner.

Jumlah responden yang diambil adalah 40 Orang. Jumlah tersebut cukup mewakili gambaran permintaan rumah tangga terhadap beras produksi Kabupaten Kubu Raya dan sudah memenuhi sampel minimal analisis regresi adalah sebanyak 30 responden (Sugiyono, 1999 ).

\section{Sumber dan Teknik Pengumpulan Data}

Data yang diperoleh meliputi Data primer dan Data sekunder. Adapun pemparan uraiannya adalah sebagai berikut :

1. Data primer, diperoleh melalui wawancara langsung dengan responden dengan bantuan daftar pertanyaan (kuisioner), responden didapatkan langsung pada pusat penjualan beras lokal Kabupaten Kubu Raya.

2. Data sekunder, yaitu data yang diperoleh dari instansi pemerintah atau lembaga lainnya yang bekaitan dengan masalah penelitian ini.

\section{Variabel Penelitian}

Adapun yang menjadi variabel pada kajian penelitian ini adalah :

1. Permintaan,yaitu jumlah beras yang diminta atau yang dibeli konsumen dalam satuan $\mathrm{Kg} / \mathrm{bulan}$.

2. Jumlah Anggota Keluarga, yaitu jumlah anggota dalam rumah tangga yang terdiri ayah, ibu, anak dan saudara. Yang ditentukan dalam satuan orang (org).

3. Pendapatan, yaitu seluruh pendapatan yang diperoleh oleh seluruh anggota keluarga yang dirata-ratakan dalam satuan $\mathrm{Rp} / \mathrm{Bulan}$.

4. Harga beras lokal, merupakan harga jual beras yang diproduksi di Kabupaten kubu Raya, yang dibayar konsumen per kilogram yang ditentukan dalam satuan $\mathrm{Rp} / \mathrm{Kg}$.

5. Harga beras non lokal, merupakan harga jual beras yang diproduksi diluar Kabupaten kubu Raya, yang dibayar konsumen per kilogram yang ditentukan dalam satuan $\mathrm{Rp} / \mathrm{Kg}$.

\section{Analisis Data}

Untuk mengetahui faktor-faktor yang mempengaruhi permintaan rumah tangga terhadap beras produksi Kubu Raya, digunakan fungsi permintaan sebagai berikut :

$$
\begin{aligned}
& \mathrm{Y}=\text { bo Jtk }{ }^{\mathrm{b} 1} \mathrm{Pdp}{ }^{\mathrm{b} 2} \mathrm{Hbl}{ }^{\mathrm{b} 3} \mathrm{Hbn}^{\mathrm{b} 4} \mathrm{e} \\
& \text { Untuk tujuan analisis, maka model atau persamaan diatas ditransformasi } \\
& \text { ke dalam bentuk linear sebagai berikut: } \\
& \text { Ln Y= } \mathrm{Yn} \beta 0+\beta 1 \ln \mathrm{Jtk}+\beta 2 \ln \mathrm{Pdp}+\beta 3 \ln \mathrm{Hbl}+\beta 4 \ln \mathrm{Hbn}+\mathrm{e} \\
& \text { Keterangan : } \\
& \mathrm{Y} \quad=\text { Jumlah beras yang diminta }(\mathrm{Kg} / \mathrm{Bulan}) \\
& \mathrm{B}_{0} \quad=\text { Konstanta } \\
& \mathrm{Jtk} \quad=\text { Jumlah Anggota keluarga (Org) } \\
& \mathrm{Pdp} \quad=\text { Pendapatan rumah tangga (Rp/Bulan) }
\end{aligned}
$$


$\mathrm{Hbl}=$ Harga beras lokal $(\mathrm{Rp} / \mathrm{Kg})$

$\mathrm{Hbn}=$ Harga beras non lokal $(\mathrm{Rp} / \mathrm{Kg})$

$b_{1-} b_{5}=$ Koefisien Regresi

$\mathrm{e} \quad=$ Error Term

\section{Uji Koefisien Determinasi $\left(\mathbf{R}^{2}\right)$}

Nilai ini digunakan untuk mengetahui ketepatan model yang digunakan yang dinyatakan dengan berapa persen variasi variabel dependen dijelaskan oleh variasi variabel independen yang dimasukkan ke dalam model regresi. Model dianggap baik apabila koefisien determinasi sama dengan satu atau mendekati satu (Gujarati, 1997). Koefisien determinasi diformulasikan sebagai berikut :

$\mathrm{R}^{2}=(\mathrm{ESS} / \mathrm{TSS})=1-(\mathrm{RSS} / \mathrm{TSS})$

$$
\text { Adjusted } R^{2}=1-\left(1-R^{2}\right) \frac{(n-1)}{(n-k)}
$$

\section{Pengujian secara serempak Uji-F (F-test)}

Uji $\mathrm{F}$ digunakan untuk mengetahui tingkat pengaruh semua variabel independen secara bersama-sama terhadap variabel dependen.

Adapun rumus $\mathrm{F}_{\text {hitung }}$ adalah (Gujarati, 1997):

$$
\begin{aligned}
\mathrm{F}_{\text {hitung }} & =\frac{\left[\left(\mathrm{R}^{2}\right) /(\mathrm{k}-1)\right]}{\left[\left(1-\mathrm{R}^{2}\right)(\mathrm{n}-\mathrm{k})\right]} \\
\mathrm{F}_{\text {tabel }} & =[(\mathrm{k}-1) ;(\mathrm{n}-\mathrm{k}) ; \alpha]
\end{aligned}
$$

Kaidah keputusan pengujian :

Jika $\mathbf{F}_{\text {hitung }}>\mathbf{F}_{\text {tabel }}$ maka Ho ditolak pada tingkat kesalahan tertentu Jika $\mathbf{F}_{\text {hitung }} \leq \mathbf{F}_{\text {tabel }}$ maka Ho diterima pada tingkat kesalahan tertentu

\section{Pengujian Secara Parsial Uji-t (t-test)}

Uji t digunakan untuk mengetahui pengaruh masing-masing variabel independen terhadap variabel dependen

Adapun rumus $\mathrm{t}_{\text {hitung }}$ adalah :

$$
\begin{aligned}
& \mathrm{T}_{\text {hitung }}=\frac{\boldsymbol{\beta}_{\mathbf{i}}}{\operatorname{Se}\left(\beta_{\mathrm{i})}\right.} \\
& \mathrm{T}_{\text {tabel }}=(\mathrm{n}-\mathrm{k} ; \alpha / 2)
\end{aligned}
$$

Kaidah keputusan pengujian :

Jika $\mathbf{t}_{\text {hitung }}>\mathbf{t}_{\text {tabel}}$, maka Ho ditolak pada tingkat kesalahan tertentu Jika $\mathbf{F}_{\text {hitung }} \leq \mathbf{t}_{\text {tabel }}$ maka Ho diterima pada tingkat kesalahan tertentu Penyimpangan Asumsi Klasik

\section{Multikolinearitas}

Uji multikolinieritas dimaksudkan untuk mengetahui apakah terdapat suatu hubungan linear antar variabel bebas yang terdapat dalam suatu model. Untuk menguji adanya gejala multikolinieritas dapat digunakan nilai eigenvalues, Tolerance (TOL), Conditional Index (CI), atau Variance Inflation Factor (VIF). Dalam penelitian ini digunakan nilai Variance Inflation Factor (VIF) sesuai di program Eviews, dimana jika nilai VIF>10 maka berarti terdapat multikolinearitas yang serius dan jika nilai $\mathrm{VIF}<10$ maka berarti tidak terdapat multikolinearitas. 


\section{Heteroskedastisitas}

Uji heteroskedastisitas digunakan untuk mengetahui apakah ada penyimpangan terhadap salah satu asumsi klasik yang mensyaratkan adanya homoskedastisitas. Heteroskedastisitas adalah adanya varian yang berbeda yang dapat membiaskan hasil yang dapat dihitung, serta menimbulkan konsekuensi adanya model yang akan dianalisis terlalu rendah dari varian yang sesungguhnya. Apabila varian unsur gangguan dalam model regresi linear tidak konstan maka terdapat penyimpangan sehingga terjadi heteroskedastisitas.

\section{Elastisitas Permintaan}

\section{Elastisitas Harga}

Elastisitas harga merupakan ukuran jumlah yang diminta terhadap perubahan harga barang tersebut ( Lipsey et al.1995) dan dapat didefinisikan sebagai berikut :

$$
\mathrm{Ep}=\frac{\text { Persentase perubahan jumlah barang yang diminta (Q) }}{\text { - Persentase perubahan harga }(P)}
$$

Acuan umum pengelompokan kategori suatu komoditi adalah sebagai berikut : 1.Ep $>1$, berarti permintaan elastic

2.Ep $<1$, berarti permintaan inelastic

3.Ep $=1$, berarti permintaan elastic tetap

4.Ep $=0$, berarti permintaan inelastic sempurna

5. Ep $=\infty$,berarti permintaan elastic sempurna

\section{Elastisitas Pendapatan}

Elastisitas pendapatan merupakan derajat reaksi permintaan terhadap perubahan pendapatan ( Lipsey et al, 1995 ), Elastisitas dapat ditulis dengan persamaan sebagai berikut :

$$
\mathrm{Ei}=\frac{\text { Persentase perubahan dalam jumlah }(\mathrm{Q})}{-------------------------}
$$

Acuan umum pengelompokan kategori suatu komoditi adalah sebagai berikut :

1. Ei $\leq 0$, berarti barang inferior

2. $0<\mathrm{Ei}<1$, berarti barang normal

3. Ei $\geq 1$, berarti barang mewah

\section{Elastisitas Silang}

Elastisitas silang merupakan besarnya reaksi terhadap perubahan hargaharga komoditi lain (Lipsey et al,1995). Persamaan elastisitas silang dapat ditulis dengan :

$$
\mathrm{E}_{\mathrm{s}}=\frac{\text { Persen Perubahan } \mathrm{Q}_{\mathrm{x}}\left(\mathrm{dQ}_{\mathrm{x}}\right)}{\text { Persen perubahan } \mathrm{P}_{\mathrm{y}}\left(\mathrm{dP}_{\mathrm{y}}\right)}
$$

Acuan umum pengelompokan kategori suatu komoditi adalah sebagai berikut :

1.Es positif, berarti merupakan substitusi

2.Es $=0$, berarti merupakan barang netral

3.Es negatif, berarti merupakan barang komplementer 


\section{HASIL DAN PEMBAHASAN}

\section{Analisis Permintaan Rumah Tangga Terhadap Beras Produksi Kabupaten} Kubu Raya.

Penelitian ini membahas tentang faktor -faktor yang mempengaruhi permintaan rumah tangga terhadap beras produksi Kabupaten Kubu Raya. Melalui analisis regresi berganda dengan metode ordinary least square (OLS) terhadap fungsi permintaan Cobb Douglas yang ditranformasikan ke dalam bentuk logaritma akan diperoleh koefisien regresi untuk semua faktor yang mempengaruhi permintaan beras.

\section{Estimasi Fungsi Permintaan}

Berdasarkan hasil analisis data diperoleh model fungsi permintaan rumah tangga terhadap beras produksi Kabupaten Kubu Raya adalah sebagai berikut :

Ln $\mathrm{Y}=-2,621+1,536 \ln \mathrm{Jtk}+0,127 \operatorname{lnPdp}-0,163 \ln \mathrm{Hbl}$

$$
+0,358 \ln \mathrm{Hbn}+\mathrm{e}
$$

Keterangan :

Y : Permintaan beras (kg/bulan)

Jtk : Jumlah anggota keluarga (orang)

Pdp : Pendapatan (Rp/bulan)

$\mathrm{Hbl}$ : Harga beras lokal ( Rp/kg)

Hbn : Harga beras non lokal ( $\mathrm{Rp} / \mathrm{kg})$

\section{Uji Asumsi Klasik}

Agar koefisien-koefisien regresi yang dihasilkan dengan metode OLS ( Ordinary Least Square) bersifat BLUE (Best Linier Unbiased Estimator), maka asumsi -asumsi persamaan regresi linier klasik harus dipenuhi oleh model. Uji penyimpangan terhadap asumsi klasik yang dilakukan meliputi uji deteksi multicollinierity dan heteroscedasticity. Data yang digunakan dalam penelitian ini adalah data Cross-Section yaitu data yang diambil pada satu satuan waktu. Asumsi yang paling sering dilanggar untuk data Cross -Section terjadinya multikolineritas dan heterokedasitas, sehingga perlu dilakukan uji untuk melihat apakah pada model yang dipilih terdapat kedua masalah tersebut atau tidak. Uji autocorrelation tidak dilakukan dalam penelitian ini karena asumsi tersebut jarang dilanggar untuk jenis data Cross -Section. Berikut ini ini adalah hasil pengujian model fungsi permintaan rumah tangga terhadap beras produksi Kabupaten Kubu Raya terhadap asumsi klasik:

\section{Uji Multikolinieritas}

Multikolinieritas berarti adanya hubungan yang sempurna atau pasti, diantara beberapa atau semua variable yang menjelaskan dari model regresi. Tepatnya multikolinieritas berkenaan dengan terdapatnya lebih dari satu hubungan linier pasti, Gujarati (199:157). Untuk mendeteksi apakah model regresi kita mengalami multikolinieritas, dapat diperiksa menggunakan VIF. VIF merupakan singkatan dari Variance Inflation Factor. Nilai VIF $>10$ berarti telah terjadi multikolinieritas yang serius di dalam model regresi Ghozali (2011). 
Tabel 1. Uji Multikolinieritas Coefficients ${ }^{\mathrm{a}}$

\begin{tabular}{|c|c|c|c|c|c|c|c|}
\hline \multirow[b]{2}{*}{ Model } & \multicolumn{2}{|c|}{$\begin{array}{l}\text { Unstandardized } \\
\text { Coefficients }\end{array}$} & \multirow{2}{*}{$\begin{array}{c}\text { Standardized } \\
\text { Coefficients } \\
\text { Beta }\end{array}$} & \multirow[b]{2}{*}{$\mathrm{T}$} & \multirow[b]{2}{*}{ Sig. } & \multicolumn{2}{|c|}{ Collinearity Statistics } \\
\hline & B & Std. Error & & & & Tolerance & VIF \\
\hline 1(Constant) & -2.621 & 10.256 & & -.256 & .800 & & \\
\hline Jtk & 1.536 & .217 & .797 & 7.071 & .000 & .760 & 1.316 \\
\hline Pdp & .127 & .110 & .122 & 1.150 & .258 & .859 & 1.164 \\
\hline $\mathrm{Hbl}$ & -.163 & 1.331 & -.014 & -.123 & .903 & .699 & 1.430 \\
\hline Hbn & .358 & .674 & .066 & .531 & .599 & .623 & 1.606 \\
\hline
\end{tabular}

Sumber : Analisis Hasil Perhitugan, Tahun 2013

Dari perhitungan uji multikolinieritas pada Tabel 1 dapat disimpulkan bahwa semua variabel bebas yang digunakan dalam penelitian ini tidak terjadi multikolinieritas karena nilai Variance Inflation Factor (VIF) kurang dari 10.

\section{Uji Heteroskedastisitas}

Uji heteroskedastisitas digunakan untuk mengetahui ada atau tidaknya penyimpangan asumsi klasik heteroskedastisitas yaitu adanya ketidaksamaan varian dari residual untuk semua pengamatan pada model regresi. Prasyarat yang harus terpenuhi dalam model regresi adalah tidak adanya gejala heteroskedastisitas. Bedasarkan tabel 2 dibawah dapat diketahui bahwa nilai korelasi ketiga variabel independen dengan Unstandardized Residual memiliki nilai signifikansi lebih dari 0,05. Karena signifikansi lebih dari 0,05 maka dapat disimpulkan bahwa tidak terjadi masalah heteroskedastisitas pada model regresi Ghozali (2011).

Tabel 2. Uji heteroskedastisitas Correlations

\begin{tabular}{|c|c|c|c|c|c|c|c|}
\hline & & & Jtk & Pdp & $\mathrm{Hbl}$ & Hbn & $\begin{array}{l}\text { standardized } \\
\text { Residual }\end{array}$ \\
\hline \multirow[t]{15}{*}{ Spearman's rho } & \multirow[t]{3}{*}{ Jtk } & Correlation Coefficient & 1.000 & .262 & .033 & -.193 & .001 \\
\hline & & Sig. (2-tailed) & . & .102 & .840 & .233 & .994 \\
\hline & & $\mathrm{N}$ & 40 & 40 & 40 & 40 & 40 \\
\hline & \multirow[t]{3}{*}{ Pdp } & Correlation Coefficient & .262 & 1.000 & .252 & .169 & -.053 \\
\hline & & Sig. (2-tailed) & .102 & . & .116 & .297 & .745 \\
\hline & & $\mathrm{N}$ & 40 & 40 & 40 & 40 & 40 \\
\hline & \multirow[t]{3}{*}{$\mathrm{Hbl}$} & Correlation Coefficient & .033 & .252 & 1.000 & $.482^{* * *}$ & .039 \\
\hline & & Sig. (2-tailed) & .840 & .116 & . & .002 & .810 \\
\hline & & $\mathrm{N}$ & 40 & 40 & 40 & 40 & 40 \\
\hline & \multirow[t]{3}{*}{ Hbn } & Correlation Coefficient & -.193 & .169 & $.482^{* *}$ & 1.000 & -.113 \\
\hline & & Sig. (2-tailed) & .233 & .297 & .002 & . & .487 \\
\hline & & $\mathrm{N}$ & 40 & 40 & 40 & 40 & 40 \\
\hline & \multirow{3}{*}{$\begin{array}{l}\text { Unstandardi } \\
\text { zedResidual }\end{array}$} & Correlation Coefficient & .001 & -.053 & .039 & -.113 & 1.000 \\
\hline & & Sig. (2-tailed) & .994 & .745 & .810 & .487 & $\cdot$ \\
\hline & & $\mathrm{N}$ & 40 & 40 & 40 & 40 & 40 \\
\hline
\end{tabular}

**. Correlation is significant at the 0.01 level (2-tailed).

Sumber : Analisis Hasil Perhitugan, Tahun 2013

Pengujian Model

Untuk menganalisa hubungan antara permintaan rumah tangga terhadap beras produksi Kabupaten Kubu Raya digunakan model regresi linear berganda dalam bentuk logaritma natural. Agar dapat memperoleh hasil regresi yang terbaik maka harus memenuhi kriteria statistik sebagai berikut : 


\section{Pengujian secara serempak Uji-F ( F-test)}

Pengujian secara serempak uji-F (F-test) ini berguna untuk mengetahui pengaruh yang signifikan secara bersama-sama atau keseluruhan antara variabel bebas yang meliputi Faktor-faktor yang mempengaruhi permintaan beras yaitu jumlah anggota keluarga, pendapatan rumah tangga, harga beras lokal, dan harga beras non lokal terhadap jumlah beras produksi Kabupaten Kubu Raya yang diminta.

Dari perhitungan yang telah dilakukan, diperoleh hasil pengujian regresi berganda secara simultan sebagai berikut:

Tabel 3. Hasil Uji F Pengaruh Variabel Independen (Ttk, Pdp, Hbl, Hbn )

Terhadap Variabel Dependen ( Y)

\begin{tabular}{|c|c|c|c|c|c|}
\hline No & Variabel & $\mathrm{F}_{\text {-hitung }}$ & $\mathrm{F}_{\text {-Tabel }}$ & Sig. & R Square \\
\hline 1 & Jumlah Anggota keluarga & \multirow{4}{*}{17,181} & \multirow{4}{*}{2,64} & \multirow{4}{*}{$0,000^{\mathrm{a}}$} & \multirow{4}{*}{0,663} \\
\hline 2 & Pendapatan Rumah Tangga & & & & \\
\hline 3 & Harga Beras Lokal & & & & \\
\hline 4 & Harga Beras Non Lokal & & & & \\
\hline
\end{tabular}

Sumber : Analisis Hasil Perhitugan, Tahun 2013

Berdasarkan Tabel 3. di atas, F-hitung sebesar 17,181 dan F-Tabel pada taraf nyata $\alpha=0,05$ sebesar 2,64. Oleh karena F-hitung lebih besar dari F-Tabel, atau dapat juga dilihat dari nilai probabilitas sebesar $0,000^{\mathrm{a}}$ yang berada di bawah $\alpha=0,05$, maka diartikan bahwa faktor permintaan yang mencakup jumlah anggota keluarga, pendapatan rumah tangga , harga beras lokal, dan harga beras non lokal berpengaruh secara signifikan terhadap jumlah beras produksi Kabupaten Kubu Raya yang diminta .

Koefisien determinasi $\left(\mathrm{R}^{2}\right)$ sebesar 0,663. Artinya 66,30\% jumlah beras produksi Kabupaten Kubu Raya yang diminta dipengaruhi oleh faktor permintaan yang mencakup jumlah tanggungan keluarga, pendapatan rumah tangga, harga beras lokal, dan harga beras non lokal sedangkan sisanya 33,70\% merupakan pengaruh faktor lain yang tidak termasuk dalam fungsi permintaan ( $\mathrm{Y}$ ).

\section{Pengujian Secara Parsial Uji-T (T-test)}

Pengujian secara parsial ini dimaksudkan untuk mengetahui faktor-faktor apa diantara variabel bebas yang paling dominan mempengaruhi jumlah beras yang diminta.

Tabel 4. Hasil Uji -T Pengaruh Variabel Independen (Jtk, Pdp, Hbl, Hbn) Terhadap Variabel Dependen ( Y)

\begin{tabular}{cllcll}
\hline No & Variabel & $\beta$ & $\mathbf{t}_{\text {hitung }}$ & $\mathbf{t}_{\text {Tabel }}$ & Sig \\
\hline 1 & JTK & 1,536 & 7,071 & 1.68595 & 0,000 \\
2 & PDP & 0,127 & 1,150 & 1.68595 & 0,258 \\
3 & HBL & $-0,163$ & $-0,123$ & 1.68595 & 0,903 \\
4 & HBN & 0,358 & 0,531 & 1.68595 & 0,903
\end{tabular}

Sumber: Analisis Hasil Perhitugan, Tahun 2013 
Dari tabel 4 menyatakan bahwa variabel jumlah anggota keluarga berpengaruh nyata terhadap permintaan rumah tangga terhadap beras produksi Kabupaten Kubu Raya pada tingkat kepercayaan $99 \%$. Hal ini ditunjukkan oleh probabilitas atau nilai signifikansi dari masing-masing variabel tersebut yang lebih kecil dari nilai $\alpha=0,01(\mathrm{P}<0,01)$.

Berdasarkan hasil analisis jumlah anggota keluarga menghasilkan koefisien regresi yang bertanda positif sebesar 1,536 yang artinya setiap penambahan anggota keluarga 1 persen (cateris paribus) maka permintaan akan meningkat 1,536 persen. Hal ini menunjukkan bahwa bila jumlah anggota keluarga naik maka jumlah beras yang diminta akan ikut mengalami peningkatan jumlah anggota keluarga berbanding lurus dengan jumlah permintaan rumah tangga terhadap beras produksi Kabupaten Kubu Raya. Berdasarkan nilai koefisien regresi parsial variabel jumlah anggota keluarga mempunyai nilai koefisien yang paling besar, sehingga variabel jumlah anggota keluarga merupakan variabel yang paling berpengaruh pada permintaan rumah tangga terhadap beras produksi Kabupaten Kubu Raya. Hasil analisis ini dapat dimengerti karena terdapat keterkaitan yang erat antara jumlah anggota keluarga dengan konsumsi beras. Gambaran jumlah penduduk di Kabupaten Kubu Raya menunjukkan peningkatan dari tahun ke tahun. Adanya peningkatan jumlah penduduk akan mengakibatkan meningkatnya permintaan rumah tangga terhadap beras produksi Kabupaten Kubu Raya.

Jumlah anggota keluarga menggambarkan potensi banyaknya konsumen yang membeli suatu barang, oleh karena itu dengan semakin meningkatnya jumlah penduduk maka kebutuhan juga akan meningkat khususnya kebutuhan akan pangan karena setiap orang membutuhkan pangan untuk pertumbuhan dan pemenuhan gizi yang dibutuhkan oleh tubuh.

Hal ini dikarenakan dengan semakin meningkatnya jumlah penduduk, maka kebutuhan pangan maupun bahan makanan akan meningkat. Oleh karena itu jumlah anggota keluarga sangat berpengaruh terhadap permintaan rumah tangga terhadap beras produksi Kabupaten Kubu Raya. Peningkatan jumlah penduduk berarti menyebabkan perubahan struktur umur. Pada permintaan beras juga mengalami perubahan karena konsumsi beras antara orang dewasa dengan anakanak maupun remaja berbeda- beda.

Peningkatan jumlah penduduk saat ini memang agak sulit untuk dikendalikan. Hal ini disebabkan program Keluarga Berencana di masyarakat sudah kurang digalakkan .Adanya program Keluarga Berencana sedikit banyak akan mengendalikan pertambahan penduduk, sehingga konsumsi atau permintaan terhadap beras akan dapat ditekan. Sebaliknya dengan kurangnya pemahaman masyarakat terhadap pentingnya Keluarga Berencana maka akan semakin meningkatkan jumlah penduduk, yang akibatnya akan meningkatkan jumlah konsumsi beras dalam masyarakat.

Sedangkan variabel pendapatan, harga beras lokal dan harga beras non lokal tidak berpengaruh nyata pada permintaan beras produksi Kabupaten Kubu Raya. Ini ditunjukkan oleh probabilitas atau nilai signifikansinya yang lebih besar dari nilai $\alpha=1 \%$, 5\%, dan $10 \%$. Hal ini kemungkinan disebabkan karena dalam pengambilan responden penelitian ini dilakukan pada satu tempat yang menjual beras lokal ( beras yang diproduksi oleh petani Kabupaten Kubu Raya) dimana harga beras lokal yang dijual tidak terlalu bervariasi. Adapun beras lokal yang 
dijual dalam kemasan $5 \mathrm{~kg}$ dan $10 \mathrm{~kg}$ bermerek dagang Langsat Mas, Anggrek Macan dan Mekar Wangi.

\section{Elastisitas Permintaan Rumah Tangga Terhadap Beras Produksi Kabupaten Kubu Raya}

Permintaan adalah banyaknya jumlah barang yang diminta pada suatu daerah tertentu dengan tingkat harga tertentu dan dalam periode tertentu. Hukum permintaan hanya berlaku bila kondisi cateris paribus atau diasumsikan faktorfaktor lain tidak mengalami perubahan.

Elastisitas permintaan mengukur perubahan relatif jumlah unit barang yang dibeli akibat adanya perubahan salah satu faktor yang mempengaruhinya.

Berdasarkan uji $-\mathrm{F}$, faktor-faktor yang digunakan sebagai penduga yang akan mempengaruhi permintaan rumah tangga terhadap beras produksi Kabupaten Kubu Raya untuk analisis permintaan statis meliputi: jumlah anggota keluarga,pendapatan keluarga,harga beras lokal dan harga beras non lokal secara bersama-sama berpengaruh sangat nyata terhadap permintaan rumah tangga terhadap beras produksi Kabupaten Kubu Raya pada tingkat kepercayaan 99\% . Hal ini ditunjukkan oleh nilai signifikansi sebesar 0,000 lebih kecil dari nilai $\alpha=$ $0,01(\mathrm{P}<0,01)$.

Berdasarkan hasil uji-T, menunjukkan bahwa variabel yang berpengaruh signifikan pada tingkat kepercayaan 99\% adalah jumlah anggota keluarga sedangkan variabel pendapatan, harga beras lokal dan harga beras non lokal tidak menunjukkan pengaruh yag signifikan. Berdasarkan analisis penelitian untuk mengetahui nilai elastisitas dari masing-masing variabel penduganya karena salah satu ciri menarik dari model logaritma berganda adalah nilai koefisien regresi menunjukkan nilai elastisitasnya .Berdasarkan Hasil analisis elastisitas permintaan rumah tangga terhadap beras produksi Kabupaten Kubu Raya.

Tabel 5. Nilai Elastisitas Permintaan Rumah Tangga Terhadap Beras Produksi Kabupaten Kubu Raya

\begin{tabular}{llcc}
\hline Variabel & \multicolumn{2}{c}{ Nilai Elastisitas } \\
\cline { 2 - 3 } & Harga & Silang & Pendapatan \\
\hline Harga Beras Lokal (Hbl) & $-0,163$ & & \\
Harga Beras Non Lokal (Hbn) & & 0,358 & \\
Pendapatan (pdp) & & & 0,127 \\
\hline
\end{tabular}

Sumber : Analisis Hasil Perhitugan, Tahun 2013

Nilai elastisitas tersebut dapat dijelaskan sebagai berikut :

Elastisitas Harga ( $\left.E_{p}\right)$

Berdasarkan analisis diketahui besarnya elastisitas harga beras lokal sebesar -0,163 .Nilai elastisitas bertanda negatif menunjukkan bahwa variabel harga beras lokal memiliki hubungan terbalik dengan permintaan rumah tangga terhadap beras produksi Kabupaten Kubu Raya,artinya jika harga beras lokal naik 1 persen maka permintaan rumah tangga terhadap beras produksi Kabupaten Kubu Raya akan turun sebesar 0,163 persen(ceteris paribus), begitu juga sebaliknya. Permintaan beras bersifat inelastis karena koefisien elastisitasnya Ep < 1, yang artinya persentase perubahan harga adalah lebih besar daripada persentase perubahan jumlah yang diminta. Permintaan komoditi yang tidak banyak 
mempunyai komoditi pengganti adalah bersifat inelastis karena kalau harga komoditi tersebut naik, para pembelinya pasti sulit memperoleh barang pengganti dan oleh karenanya harus tetap membeli barang komoditi tersebut. Oleh sebab itu permintaan tidak banyak berkurang sedangkan kalau komoditi tersebut turun, permintaannya tidak banyak bertambah karena tidak banyak tambahan pembeli yang berpindah dari membeli komoditi yang bersaing dengan komoditi tersebut. Kategori suatu komoditi seperti bahan makanan, BBM, sepatu atau komoditi kebutuhan pokok cendrung bersifat inelastis atau tidak terpengaruh oleh kenaikan harga. Tetapi komoditi mewah seperti mobil, jika harganya mengalami kenaikan, orang dapat menggantikannya dengan komoditi substitusi.

Analisis harga beras menghasilkan koefisien regresi yang bertanda negatif. Hal ini menunjukkan bahwa bila harga beras naik maka jumlah beras yang diminta akan turun. Hasil penelitian menunjukkan kenaikan jumlah beras yang diminta ini disebabkan oleh kenaikan harga beras.

Harga merupakan salah satu faktor utama yang sangat diperhatikan oleh konsumen untuk mengambil keputusan dalam pembelian suatu barang. Oleh karena itu,apabila di dalam suatu pasar menjual sejenis barang yang mempunyai manfaat atau kegunaan yang sama, maka konsumen akan lebih memilih untuk membeli barang yang harganya lebih murah.

Harga komoditi pertanian, seperti harga beras relatif berfluktuasi. Hal ini dapat dipengaruhi oleh musim, dimana saat musim panen produk beras melimpah sehingga harga rendah maka permintaan konsumen terhadap beras meningkat. Sedangkan pada musim paceklik, produk beras menurun sehingga harga melambung tinggi yang mengakibatkan menurunnya permintaan konsumen terhadap komoditi ini. Hal tersebut sesuai dengan hukum permintaan oleh Sudarman ( 2000 ) menyatakan secara umum bila harga suatu komoditas tinggi, maka hanya sedikit orang yang mau dan mampu membelinya. Akibatnya jumlah komoditas yang dibelinya hanya sedikit saja. Kalau harga komoditas tersebut diturunkan, maka lebih banyak orang yang mau dan mampu membeli, sehingga jumlah komoditas yang dibeli semakin banyak. Jadi apabila harga beras itu sendiri naik maka permintaan beras akan menurun. Sehingga konsumen akan mengurangi konsumsi terhadap beras dan beralih atau memilih membeli pengganti yang harganya lebih murah dengan manfaat yang hampir sama.

Elastisitas Silang $\left(\mathrm{E}_{\mathrm{c}}\right)$

Berdasarkan analisis diketahui bahwa elastisitas silang harga beras non lokal adalah 0,358 artinya jika harga beras non lokal naik 1 persen maka permintan rumah tangga terhadap beras produksi Kabupaten Kubu Raya akan naik sebesar 0,358 persen, begitu juga sebaliknya. Tanda positif pada nilai elastisitas harga beras non lokal menunjukkan bahwa beras non lokal merupakan barang substisusi dari beras lokal ( beras yang diproduksi oleh petani Kabupaten Kubu Raya). Suatu barang dikatakan sebagai barang substitusi jika barang tersebut penggunaannya dapat menggantikan barang lain. Pada penelitian ini beras non lokal diasumsikan sebagai barang substitusi bagi beras lokal atau beras yang diproduksi oleh petani Kabupaten Kubu Raya.

Permintaan suatu barang pengganti akan naik bila harga barang substitusinya naik. Begitu sebaliknya bila harga barang pengganti turun , maka permintaan permintaan akan barang tersebut juga turun. 
Menurut Soekartawi ( 1989 ) berpendapat bahwa elastisitas silang adalah besaran elastisitas yang tidak saja menunjukkan perubahan suatu barang yang diminta saja, tetapi juga terhadap perubahan barang lain yang berkaitan dengan barang yang diminta tersebut.

Didalam suatu perekonomian terdapat banyak barang yang dapat digantikan dengan barang - barang lain yang sejenis dengannya, tetapi adapula yang sukar mencari penggantinya. Perbedaan ini menimbulkan perbedaan elastisitas diantara berbagai macam barang. Sekiranya suatu barang mempunyai banyak barang pengganti,maka permintaan cendrung bersifat elastis,perubahan harga yang kecil saja akan menimbulkan perubahan yang besar atas permintaan. Pada waktu harga naik, para pembeli akan merasa enggan membeli barang tersebut, mereka lebih suka menggunakan barang-barang lain yang menjadi penggantinya, yang harganya tidak mengalami perubahan. Sebaliknya pada waktu harga turun, para pembeli melihat bahwa barang tersebut lebih murah daripada barang-barang penggantinya dan beramai-ramai membeli barang tersebut, ini menyebabkan permintaannya bertambah dengan cepat. Permintaan barang-barang yang tidak mempunyai barang pengganti adalah bersifat tidak elastis, karena kalau harga naik para pembelinya sukar memperoleh barang pengganti dan oleh karenanya harus tetap membeli barang tersebut.

Dari uraian sebelumnya dapat disimpulkan bahwa semakin banyak jenis pengganti atau sesuatu barang, maka semakin elastisitas permintaannya.

Elastisitas Pendapatan ( Ei )

Berdasarkan analisis di ketahui bahwa elastisitas permintaan terhadap pendapatan mempunyai hubungan positif ,karena perubahan pendapatan dan perubahan permintaan bergerak searah nilai koefisien regresi 0,127 yang berarti jika terjadi kenaikan pendapatan sebesar 1 persen, maka akan mengakibatkan bertambahnya permintaan beras sebesar 0,127 persen begitu juga sebaliknya. Angka elastisitas pendapatan rumah tangga yang lebih kecil dari satu bertanda positif $(0<\mathrm{Ei}<1)$, menunjukkan beras termasuk komoditi barang normal yaitu barang- barang konsumsi yang jumlah pemakainnya bertambah apabila pendapatan konsumen bertambah sebaliknya jumlah pemakaian berkurang apabila pendapatan konsumen berkurang(Kotler,1991). Berdasarkan hasil penelitian Wiwin(2010)" Analisis Permintaan Beras di Kabupaten Pati " menunjukkan bahwa elastisitas pendapatan ,beras merupakan barang normal.

Pendapatan merupakan faktor yang dalam menentukan variasi permintaan terhadap berbagai jenis barang karena besar kecilnya pendapatan dapat menggambarkan daya beli konsumen. Bila terjadi perubahan dalam pendapatan maka akan menimbulkan perubahan dalam mengkonsumsi berbagai jenis barang. Hal ini dapat diterima karena semakin tinggi pendapatan seseorang lebih cendrung mementingkan prestice, artinya dengan pendapatan yang tinggi masyarakat akan berusaha menunjukkan bahwa makanannya tidak hanya beras, melainkan roti,daging. maupun vitamin seperti sayur-sayuran dan buah-buahan.

Seiring waktu berjalan terjadi peningkatan pendapatan keluarga secara terus menerus sehingga persentase pendapatan yang dibelanjakan semakin bertambah. Hal ini kemungkinan disebabkan karena sudah menjadi kebiasaan bahwa semakin tinggi pendapatan seseorang akan berusaha meningkatkan kualitas hidup seperti memenuhi konsumsinya dengan makan diluar atau memenuhi kebutuhan selain pangan ini sesuai dengan teori yang dikemukakan oleh Engel 
dalam Nicholson (1999) bahwa semakin tinggi pendapatan masyarakat, maka akan semakin sedikit proporsi pendapatan yang digunakan untuk membeli makanan pokok. Hipotesis itu dikenal dengan Hukum Engel. Fungsi Engel menunjukan pengaruh dari penghasilan rumah tangga terhadap konsumen rumah tangga.

\section{KESIMPULAN}

Berdasarkan pada uraian hasil penelitian dan pembahasan maka dapat diperoleh kesimpulan sebagai berikut:

1. Faktor -faktor yang mempengaruhi permintaan rumah tangga terhadap beras produksi Kabupaten Kubu Raya adalah jumlah anggota keluarga sedangkan pendapatan rumah tangga, harga beras lokal serta harga beras non lokal tidak menunjukkan pengaruh nyata terhadap permintaan rumah tangga terhadap produksi beras Kabupaten Kubu Raya.

2. Elastisitas permintaan rumah tangga terhadap beras produksi Kabupaten Kubu Raya menunjukkan bahwa elastisitas harga atas permintaan rumah tangga terhadap beras produksi Kabupaten Kubu Raya adalah inelastis, Elastisitas pendapatan menunjukkan bahwa beras lokal ( beras yang diproduksi oleh petani Kabupaten Kubu Raya ) termasuk dalam katagori barang normal .Beras non lokal ( beras yang diproduksi oleh petani diluar Kabupaten Kubu Raya ) dapat dikategorikan sebagai barang substitusi dari beras non lokal( beras yang diproduksi oleh petani Kabupaten Kubu Raya )

SARAN berdasarkan hasil analisis elastisitas harga silang.

1. Beras merupakan makanan pokok dimana permintaan beras setiap tahunnya meningkat seiring dengan pertambahan penduduk untuk itu perlu adanya upaya untuk menjaga ketersediaan beras agar kebutuhan akan beras dapat selalu terpenuhi mengingat yang paling besar mempengaruhi permintaan beras adalah jumlah anggota keluarga.

2. Untuk penelitian selanjutnya, dapat melakukan penelitian mengenai analisis permintaan rumah tangga terhadap beras produksi Kabupaten Kubu Raya dengan menambah variabel-variabel baru yang lebih dapat menjelaskan mengenai permintaan beras produksi Kabupaten Kubu Raya dan memperbanyak lokasi pengambilan sample tidak terpusat pada satu tempat yang menjual beras produksi Kubu Raya tetapi dapat mengambil sampel pada toko, supermarket maupun pada Koperasi Gabungan Kelompok tani yang menjual beras produksi Kubu Raya

\section{DAFTAR PUSTAKA}

Achmad Suryana dan Sudi Mardiyanto. 2001. Bunga Rampai Ekonomi Beras. Jakarta. LPEM-FEUI.

Anonim. 1996. Undang-undang No. 7 tahun 1996 tentang Pangan.

Badan Pusat Statistik. 2011. Kabupaten Kubu Raya Dalam Angka Tahun 2011. Katalog BPS : 1102001.611. Kubu Raya, Kalimantan Barat.

Badan Pusat Statistik. 2008. Kalimatan Barat Dalam Angka. Tahun 1997-2007.

Daniel, M. 2002. Penelitian Ekonomi. UI- Press. Jakarta. 
Gilarso, T. 1993. Pengantar Ilmu Ekonomi bagian Mikro. Kanisius. Yogyakarta.

Gujarati, Damodar. 1995. Dasar-dasar Ekonometrika. Jakarta : Penerbit Erlangga.

Hapsari, Rinawati Dwi. 2011. Analisis Faktor-Faktor Yang Mempengaruhi Permintaan Beras Organik Di Kabupaten Sragen Tahun 2005 - 2010. Skipsi Dipublikasikan. Dari : http://digilib.uns.ac.id/pengguna.php? $\underline{m n=s h o w ~ v i e w \& i d=20067}$. Diakses pada tanggal 12 Januari 2013.

Kotler, Philip. 1991. Manajemen Pemasaran Analisis Perencaan, Implementasi dan Pengendalian (Volume I). Erlangga. Jakarta.

Lipsey, R.E. 1993. Economics. Tenth Edition. Harper and Row Publisher. New

York.

Mulyo. W, Hendrik 2008. Analisis Permintaan Beras Di Kabupaten Klaten. Skipsi Dipublikasikan. Dari : http://isearch.avg.com/search?q=jurnal +tentang+analisis+ permintaan+beras \&sap=nt\&l ang=id\&mid=f5648 33f526b47d1a56d3d1cbf452ee8-71ade3bf9bd555c71d5ce7c9843fb010e 7 $\mathrm{d} 09 \mathrm{~b} 22 \& \mathrm{cid}=\{\mathrm{e} 849 \mathrm{e} 817-21 \mathrm{cf}-425 \mathrm{f}-8 \mathrm{bfb}-\mathrm{feec} \quad 706 \mathrm{~b} 5 \mathrm{~b} 9 \mathrm{c}\} \& \mathrm{v}=13.2 .0 .5$ $\& \mathrm{ds}=\mathrm{AVG} \& \mathrm{~d}=18 \% 2 \mathrm{~F} 06 \% 2 \mathrm{~F} 2012+19 \% 3 \mathrm{~A} 45 \% 3 \mathrm{~A} 49 \& \mathrm{pr}=\mathrm{fr} \& \mathrm{snd}=\mathrm{hdr}$. Diakses pada tanggal 12 Januari 2013.

Nazir. 1983. Metode Penelitian. Ghalia Indonesia. Bandung.

Soegiyono. 2005. Statiska Untuk Penelitian. CV ALFABETA. Jakarta.

Soekartawi, 1989. Prinsip Dasar Ekonomi Pertanian Teori dan Aplikasi. Cetakan kedua. Jakarta: CV. Rajawali.

Swastha, Basu dan Handoko, T. Hani. 1987. Manajemen Pemasaran. Edisi ke tiga. Penerbit Erlangga, Jakarta.

Wiwin, Endang. 2010. Analisis Permintaan Beras di Kabupaten Pati. Skripsi Dipublikasikan. Dari : http://digilib.uns.ac.id/pengguna.php?mn= showview \&id=22812. Diakses pada tanggal 12 Januari 2013 